\title{
THE SKEPTICAL CARTESIAN BACKGROUND OF HUME'S “OF THE ACADEMICAL OR SCEPTICAL PHILOSOPHY” (FIRST INQUIRY, SECTION 12)
}

\author{
José R. Maia Neto* \\ jrmaia@ufmg.br
}

RESUMO Na seção XII da Primeira Investigação, Hume refere-se a duas escolas céticas antigas (academia e pirronismo) ao apresentar sua própria visão do ceticismo que, entretanto, depende do ceticismo antigo somente secundária e indiretamente. A compreensão humiana do ceticismo depende principalmente de Descartes e de filósofos pós-cartesianos como Pascal, Huet, Foucher e Bayle que reagiram ceticamente às principais doutrinas cartesianas, mas seguiram uma versão ou outra da dúvida metódica de Descartes. Embora todos estes filósofos sejam relevantes na seção XII, examinarei os tópicos da seção nos quais Descartes (além dos céticos modernos citados) parece ser diretamente visado. Após uma seção introdutória (I) sobre as leituras de Julia Annas e Richard Popkin da relação de Hume com, respectivamente, o ceticismo antigo e o moderno, examino o que Hume chama na seção XII da Investigação de (II) "ceticismo consequente sobre os sentidos", (III) "ceticismo antecedente" e (IV) "ceticismo acadêmico".

Palavras-chave Hume, Ceticismo, Descartes, Pascal, Foucher, Bayle, Huet, Popkin.

* Universidade Federal de Minas Gerais (UFMG). I thank CNPq for a research grant. A first version of this paper was presented at the $40^{\text {th }}$ International Hume Society Conference, Belo Horizonte, 2013. I thank all those who commented on the paper at that occasion. Artigo recebido em 15/12/2014 e aprovado em 22/04/2015. 
ABSTRACT In section XII of the First Inquiry, Hume refers to the two Hellenistic schools of skepticism (Academic and Pyrrhonian) to present his own view of skepticism, which, however, depends on the ancient skeptics mainly indirectly. Hume's view of skepticism depends crucially on Descartes and post-Cartesian philosophers such as Pascal, Huet, Foucher and Bayle, who reacted skeptically to major Cartesian doctrines but followed one version or other of Descartes's methodical doubt. Although all these post-Cartesian philosophers are relevant in section XII, I focus on the topics in which Descartes himself-besides his skeptical followers-seems directly relevant. After an introductory section (I) on Julia Annas' and Richard Popkin's views of Hume's relation to, respectively, ancient and modern skepticism, I turn to section XII and examine what Hume calls (II) "consequent skepticism about the senses," (III) "antecedent skepticism," and (IV) "Academic skepticism."

Keywords Hume, Skepticism, Descartes, Pascal, Foucher, Bayle, Huet, Popkin.

\section{Annas and Popkin}

Bringing in Descartes and the late seventeenth-century skeptical Cartesians is crucial to understand Hume's skepticism and his view of skepticism, both the modality he calls "Pyrrhonian" and the modality he calls "Academic". ${ }^{1}$ If we disregard the history of skepticism from Omer Talon in the mid sixteenthcentury to Pierre Bayle at the end of the seventeenth-century, we may come up to a very negative view of Hume's knowledge of the history of philosophy, at least as far as skepticism is concerned. The great Hellenistic scholar Julia Annas (2000, pp. 271-272) compared what Hume calls Pyrrhonian and Academic skepticism with these two Hellenistic schools and recognized that the results of this comparison were quite disappointing. She points out how "indeed unsophisticated" is Hume's objection that Pyrrhonism cannot be sustained in ordinary life, apparently ignoring Sextus' many arguments to the contrary $(2000$, p. 275). She also points out how "startling" is Hume's lack of

1 Hume's view of skepticism also depends on the "dogmatic" (in the Pyrrhonian technical sense of holding doctrines) "Cartesians'" (in the broad sense the term was understood at the time) strong negative reactions to skepticism, for instance Arnauld's and Nicole's "Logique de Port-Royal" and Malebranche's "Recherche de la Vérité", both works cited in Hume's "Dialogues Concerning Natural Religion”, respectively in parts I and II. Hume's view of skepticism also depends on the critics of skepticism of the early eighteenth-century. See Popkin (1952) and Paganini (2010). 
acknowledgement of the similarities between the ancient Pyrrhonian view of phenomena and his view of nature (2000, p. 276). Hume's apparent ignorance of the other brand of Hellenistic skepticism-Academic skepticism-is also remarked by Annas. It makes no sense to consider it a mitigated version of Pyrrhonian skepticism since it was as radical (Annas, 2000, pp. 276-277). Her conclusion, with which I concur, is that although Hume knew Sextus' works which he refers to a couple of times, "Hume gets nothing out of Sextus about scepticism" (Annas, 2000, p. 272). ${ }^{2}$ These negative results show not Hume's ignorance or lack of understanding of Sextus and the ancient Academic skeptics but that the modern skeptics, not the ancient ones, were his main sources for skepticism. ${ }^{3}$ All of these views of skepticism held by Hume make sense if we bear in mind that the skepticism he is talking about is not the Hellenistic but the early modern post-Cartesian one. It is debatable if ancient Pyrrhonism is tenable in practical life, ${ }^{4}$ but that Cartesian skepticism ${ }^{5}$ is absolutely untenable from the practical point of view is a recognized fact by Descartes, his critics, followers and scholars. I argue that what Hume calls "Pyrrhonian skepticism" is basically this kind of Cartesian skepticism, articulated by Descartes and the late seventeenth-century skeptics aforementioned, and enhanced by skeptical arguments of Hume's own. The force of "nature", which prevents the philosopher from sustaining his épochè, may be remotely related to the ancient Pyrrhonians' phenomena but is directly related to Descartes's and Pascal's own, and Bayle quoting Pascal, and Crousaz criticizing Bayle, contraposition between skepticism and nature. Finally, the view of Academic skepticism as a milder form of skepticism is found in most early modern philosophers who dealt with the subject.

Before turning to section XII, I should mention that the skeptical Cartesian background of Hume's skepticism was the main motivation behind Richard

2 This means that the question of which edition of Sextus Hume might have read is not much relevant since his sources for skepticism are-except for Cicero and Plutarch-all modern. See Groarke and Solomon (1991), Popkin (1993), and Annas (2000, pp. 272-273). For a different view on the relevance of ancient Pyrrhonism for Hume's philosophy, see Baxter, forthcoming.

3 With the partial exception of the "Dialogues Concerning Natural Religion", in which Annas identifies a more accurate view of ancient Pyrrhonism. I briefly discuss Hume's "Dialogues" at the end of this paper.

4 Whenever there were skeptics there also were critics claiming that skepticism is not tenable in ordinary life. In Hellenism, one can cite Diogenes Laertius' report of Antigonus of Carystus' view of Pyrrho as needing the help of dogmatic friends to avoid falling into cliffs. See Diogemes Laertius (1925, XI.62). In modernity, one might cite the (in)famous claim of Arnauld and Nicole (1970, p. 39) that "le Pyrrhonism n'est pas une Secte de gens qui soient persuadés de ce qu'ils disent; mais c'est une Secte de menteurs". Hume refers to this passage in the "Dialogues" (1986, p. 9). Among contemporary Hellenistic scholars, one can cite Myles Burnyeat's (1980) negative answer to the title of his paper "Can the Skeptic live his skepticism?".

5 By 'Cartesian skepticism' I mean Descartes's doubt and the skeptical consequences post-Cartesian philosophers derived from his views. 
Popkin's original project of the history of modern skepticism. We learn from Popkin's autobiography (1988) and his correspondence recently made available by Popkin's son, the historian of ideas Jeremy Popkin, that the birth place of Popkin's research was a graduate seminar he attended at Yale in 194546 on Hume given by Charles Hendel (J. Popkin, 2009). Popkin perceived striking similarities between Sextus and Hume and wondered how historically Hellenistic skepticism managed to get to the eighteenth-century. To answer this question he planned the book that has become a classic in the historiography of philosophy. In the original plan of the "History of Scepticism", Hume would be the subject of the last concluding chapter. ${ }^{6}$ Popkin's first published article on skepticism was "David Hume: His Pyrrhonism and His Critique of Pyrrhonism" (1951), which probably derived from the term paper he wrote for Hendel's seminar (J. Popkin, 2009, pp. 18-19). As Jeremy noted, Richard Popkin never completed the project of carrying his history of skepticism to Hume. After finishing the first edition "From Erasmus to Descartes" (Van Gorcum, 1961), he worked a lot on Bayle and planned to work on Huet (J. Popkin, 2009, p. 30), for both were central figures to connect Hume to the skeptical tradition. Part of his studies on post-Cartesian skepticism (not only on Huet and Bayle, but also on Glanvill, Pascal, Foucher and Locke) was incorporated in the last edition of "The History of Scepticism from Erasmus to Bayle", published in 2003 by Oxford University Press, just two years before his death. ${ }^{7}$ What follows is my own view (not Popkin's) of what should be some of the main lines of that concluding chapter that Popkin never managed to write, linking Hume to the late seventeenth-century skeptics. ${ }^{8}$

\section{Consequent skepticism about the senses}

In the first part of section XII, Hume distinguishes antecedent from consequent skepticism. Antecedent skepticism is a precautionary provision

6 In a research project Popkin wrote at the time he claimed that his goal was "to discover the historical antecedents of the sceptical philosophy of David Hume. ... My hope is to publish my results in the form of a book on the history and influence of Pyrrhonism from Montaigne to Hume" (cited by J. Popkin, 2009, p. 23). In another paper, Jeremy Popkin claims that his father's initial project was "an inquiry into the origins of David Hume's ideas," which "broadened into The History of Scepticism" (2008, p. 264).

7 Part of this material was previously published in articles, some of which were assembled by Richard Watson and James Force in Popkin (1980).

8 What would be Popkin's own view of Hume's relation to these post-Cartesian skeptics? In a letter to Robert Turnbull he discloses what his thoughts on this issue were in 1953: "I have found the proper link between Bayle and Hume, and can now prove that Hume's main originality is not philosophical, but only psychological. On all else he had been long anticipated, or else he misunderstood the point at issue" (J. Popkin, 2008, p. 265). 
made by the inquirer before the epistemological inquiry, the result of which is consequent skepticism. Each of these is further divided into two kinds, one that Hume dismisses, and another he recommends and develops. I comment first on consequent and then on antecedent skepticism.

Consequent skepticism is divided into popular and philosophical. The former is immediately dismissed whereas the latter-divided into skepticism about the senses, about reason and about reasonings concerning matters of fact-is the subject of parts I and II of section XII. On skepticism about the senses, Hume writes: "I need not insist upon the more trite topics, employed by the sceptics in all ages, against the evidence of the sense" (E, p. 151). This is, apart from a footnote mentioned bellow, the unique occasion in the first Inquiry and in the whole Treatise where Hume refers to the ancient skeptics. ${ }^{9}$ These skeptical topics are some of the ancient Pyrrhonian ten modes available to us through Sextus Empiricus' "Outlines of Pyrrhonism" (I.36-163), Diogenes Laertius' "Life of Pyrrho" (IX.80-88) and, in an abbreviated and much less known report, Philo of Alexandria's "On Drunkenness" (169-202). Hume gives as examples the case of the variations of visual images deriving from different distances (seventh mode in Diogenes Laertius' classification, fifth in Sextus'), the image of a crooked oar immersed in water (sixth mode), and the case of double visual images caused by pressing one's eyes. These two last examples are not found in the available sources of ancient Pyrrhonism but in the most complete available source of ancient Academic skepticism we have, Cicero's "Academica". ${ }^{10}$ However, instead of discussing these and similar cases of sense deception, he says he will examine "other more profound arguments against the senses" held by "the more philosophical sceptics" (E, pp. 51-153). ${ }^{11}$ Hume's distinction of the two subtypes corresponds exactly to the

9 Both references to the ancient skeptics are only indirect. In section I of the First Inquiry, Hume refers to Cicero's fame but not in connection to his skepticism.

10 Cicero, defending Academic skepticism, tells Luculus, who supports Antiochus' Stoicism: "Yet you assert that the broken oar and the pigeon's neck do not upset you. In the first place why? For in the instance of the oar I perceive that what is seen is not real ... Accordingly, Timagoras the Epicurean denies that he has ever really seen two little flames coming from the lamp when he has screwed up an eye" (Cicero, Ac II.80).

11 In part II Hume reiterates the distinction, introducing skepticism about reasonings concerning matters of fact: "The sceptical objections to moral evidence, or to the reasonings concerning matter of fact, are either popular or philosophical. The popular objections are derived from [a] the natural weakness of human understanding; [b] the contradictory opinions, which have been entertained in different ages and nations; [c] the variations of our judgement in sickness and health, young and old age, prosperity and adversity; [d] the perpetual contradiction of each particular man's opinions and sentiments; with many other topics of that kind. It is needless to insist farther on this head. These objections are but weak" (E, p. 158). The main sources of each popular skeptical objection indicated by Hume are the following: [a] is an ancient skeptical view, which was much insisted upon by modern skeptics imbued by the Christian view of the vanity and misery of man. Hume's sentence calls to mind the title of bishop Pierre-Daniel Huet's most skeptical book, "An Essay Concerning the Weakness of Human Understanding", published in English in 1725, just two 
distinction between ancient and modern skepticism, "modern" here meaning Cartesian skepticism. ${ }^{12}$ Indeed, these profound arguments are proposed by the "modern enquirers" (E, p. 154). ${ }^{13} \mathrm{He}$ dismisses the ten modes saying that they can easily be responded by taking into account the ideal conditions of perception, as it was earlier argued by Gassendi in the "Logica" of his "Syntagama" and by many others. ${ }^{14}$ A similar distinction between ancient and modern skepticism, with an equivalent dismissal of the former, was made by Descartes in the First Meditation, when he introduces hyperbolic doubt: "Yet although the senses occasionally deceive us with respect to objects which are very small or in the distance, there are many other beliefs about which doubt is quite impossible, even though they are derived from the senses-for example, that I am here, sitting by the fire...." (CSM, II, 12-13). These basic beliefs which are not ordinarily doubted are doubted through the famous skeptical scenarios of the dream and the deceiver, which are originally Cartesian in their scope. ${ }^{15}$ The perceptual mistakes originated by the senses in ancient Pyrrhonian fashion are also considered by Descartes as ordinary, unlike the metaphysical or hyperbolic doubts raised in the First Meditation. Pascal makes a similar distinction when he considers "les principales forces des pyrrhoniens", leaving aside "les moindres comme les discours qu'on faits les pyrrhoniens contre les impressions de la coutume, de l'éducation, des moeurs des pays, et

years after the posthumous publication of the French version (the original Latin was published only in 1738). Hume alludes to this book of Huet's in the "Dialogues Concerning Natural Religion", part I. [b] is the classical skeptical trope of diaphonia, exploited in Sextus' tenth mode, which was much emphasized by Renaissance skeptics (Gianfrancesco Pico della Mirandola, Montaigne, Charron), by the skeptic La Mothe Le Vayer and even by Descartes in the "Discourse on the Method", parts I, II and III. [C] are exempla of Sextus' fourth mode which was also rehearsed by Renaissance skeptics such as Montaigne, who insisted, in particular, on [d] (see "Essays", II, 12, pp. 637-642).

12 Because by "modern skepticism" I mean here Cartesian skepticism, I am considering at this point as "ancient" the reception of ancient skepticism by Gianfrancesco Pico della Mirandola, Montaigne, Charron, La Mothe le Vayer, Gassendi and other pre-Cartesian skeptics. Some post-Cartesian skeptics such as Huet also rehearse the ancient skeptical tropes but they are mixed with Cartesian doctrines skeptically interpreted (see Huet, 1725, I. 3, 5-6, 8-9).

13 The most relevant ones are Descartes, Malebranche, Foucher, Bayle, Huet, Locke, Berkeley and of course, above and building on them all, Hume. Of these, Hume names only Descartes in the body of the text, and Bayle and Berkeley in a footnote. "This argument [namely, that "an extension, that is neither tangible nor visible, cannot possibly be conceived"] is drawn from Dr. Berkeley; and indeed most of the writings of that very ingenious author form the best lessons of scepticism, which are to be found either among the ancient or modern philosophers, Bayle not excepted" (E, p. 155n).

14 Gassendi's "Syntagma" was published posthumously in 1658. For other philosophers who replied along similar lines to the skeptical modes, see Popkin (2003, pp. 105-111). Hume says that these popular skeptical paradoxes "are to be met with in some philosophers, and the refutation of them in several" (E, p. 151).

15 Versions of the dream argument appear in Sextus' "Outlines" (the fourth mode-PH I.104) and Cicero's "Academica" (Ac II.52), a book in which Curley (1978, pp. 68-69) has also pointed out a primitive version of the God deceiver argument. I agree with Burnyeat (1982) that these ancient skeptical arguments do not put in doubt the existence of an external material world. 
les autres choses semblables" (La 131). Pascal's distinction resembles Hume's to the extent that he says that ancient Pyrrhonism may be set aside since the strongest skeptical arguments are the Cartesian ones concerning the problem of distinguishing wake from dream perceptions and that of the uncertainty of our origin, and so of our faculties (La 131).

If the philosophical skepticism explored by Hume is Cartesian why does he call it "Pyrrhonian"? As Pascal's reception of Descartes's doubt illustrates, this doubt was immediately related to the Pyrrhonian ancient tradition. ${ }^{16}$ Bayle claimed in the article "Pyrrho" of the "Dictionary" that Pyrrhonism was stronger in modernity than it ever was in antiquity mainly because of Cartesianism. ${ }^{17}$ Hume and many others who read Huet's "Traité Philosophique" called "Pyrrhonian" the Cartesian skepticism of the work ("Dialogues", p. 10). One of such interpretations was by Jean-Pierre Crousaz who published a 2,500 page "Examen du Pyrrhonisme ancien et modern" (La Haye: Pierre de Hondt, 1733), 350 pages of which dedicated to Sextus, 90 to Huet and 1,800 to Bayle. ${ }^{18}$

Descartes's and Pascal's strongest skeptical arguments are among the philosophical consequent skeptical arguments dealt with by Hume in part I. The philosophical arguments against the senses are two, the first is the problem of the veil of ideas, the second is the problem of distinguishing primary from secondary qualities. Both put in doubt the existence of an external material world. The first problem was first raised by Descartes in the "Meditations". ${ }^{19}$ Hume says that philosophy teaches us that we have no direct access to external material objects since our perception of them is mediated by ideas which we ordinarily assume to be identical or caused by the external objects and, if caused, to resemble them. Belief in external material objects is a sentiment, an "instinct" or "propensity" of nature that the profound or philosophical skeptic shows to be ungrounded by reason. So when philosophers attempt to prove the existence of external material objects they cannot appeal to this deceiving

16 See, for instance, Arnauld and Nicole's view of the Pyrrhonians referred to in footnote 4 above. For other references, see Popkin (2003, pp. 158-173).

17 "I will not make use of the advantages the new philosophy has given the Pyrrhonists. ... Cartesianism put the final touches to this, and now no good philosopher any longer doubts that the skeptics were right to maintain that the qualities of bodies that strike our senses are only appearances" (Bayle, 1991, p. 197).

18 Popkin (1952) and Paganini (2010) claim that Crousaz influenced Hume's view of skepticism.

19 The problem was also discussed, in the footsteps of Descartes, by Malebranche (who claimed that only Scripture could certify the existence of an external material world), Foucher (who, anticipating Berkeley, developed a proto idealism he qualified as Academic), Bayle (whose exploitation of the problem was among Hume's main sources), Huet, Locke, Berkeley and others. I do not examine how they may have influenced Hume's treatment of the problem. Hume's reading of Descartes's view of ideas as representative entities is polemical and certainly influenced by the late seventeenth-century skeptics' reception of Cartesianism. 
sentiment nor rationally demonstrate their existence, for, unlike ideas, matters of fact cannot be demonstrated.

The problem set up by Hume appears in the Third Meditation where Descartes argues that our natural belief on adventitious ideas is unsupported by the natural light of reason. Descartes says that belief in the external material world derives from a "spontaneo impetus" (AT, VII, 38), ${ }^{20}$ an "impetus naturales" (AT, VII, 39), ${ }^{21}$ which is not trustful, first because natural impulses often play us wrong as we sometimes learn from our moral choices and, second, these perceptions may have other causes unrelated to the supposed external material object. These may be either internal-as in dreams-or external but non material such as evil demons or God. "All these considerations," Descartes concludes, "are enough to establish that is not reliable judgement but merely some blind impulse ${ }^{22}$ that has made me believe up till now that there exist things distinct from myself which transmit to me ideas or images of themselves through the sense organs" (CSM, II, 27). This same blind natural impetus makes us believe that not only our perceptions are caused by an external object but also that they either are or resemble qualities really existent in the external objects.

As is well known, only in the Sixth Meditation is Descartes in conditions to give an answer to skepticism about the external material world. The proof provided by Descartes there is criticized by Hume in section XII. "By what argument can it be proved, that the perceptions of the mind must be caused by external objects, entirely different from them, though resembling them (if that be possible) and could not arise either from the energy of the mind itself, or from the suggestion of some invisible and unknown spirit, or from some other cause still more unknown to us? It is acknowledged, that, in fact, many of these perceptions arise not from anything external, as in dreams, madness, and other diseases" (E, pp. 152-153). In the Sixth Meditation, Descartes raises precisely these alternative causes for sense perception and rules them out, arguing that only the external material objects can be the cause of our sensible ideas. After the knowledge of the mind acquired through the six Meditations we know that we do not have such a hidden faculty capable of causing ideas of external material objects. And because we also learned with clarity and

20 Luyne's French translation revised by Descartes: "certaine inclination qui me porte..." (AT, IX, 30). CSM, II, 26: "a spontaneous impulse leads me to believe".

21 Luynes' translation: "inclinations qui me semblent aussi m'estre naturelles” (AT, IX, 30). CSM, II, 27: "natural impulses".

22 Latin original: "ex caeco aliquo impulsu" (AT, VII, 40). Luynes' translation: "impulsion aveugle \& temeraire" (AT, IX, 31). 
distinction that God exists and is not a deceiver, we can rule out that either he or some evil genius is causing such ideas. ${ }^{23}$ Hume replies that

to have recourse to the veracity of the supreme Being, in order to prove the veracity of our senses, is surely making a very unexpected circuit. If his veracity were at all concerned in this matter, our senses would be entirely infallible; because it is not possible that he can ever deceive. Not to mention, that, if the external world be once called in question, we shall be at a loss to find arguments, by which we may prove the existence of that Being or any of his attributes. (E, p. 153)

Descartes of course does not attempt to prove the existence of God and his attributes from the external world, but from the innate idea of God. And he also has a reply to the problem of reconciling God's veracity with ordinary sense deceptions, a problem that was also raised by Bayle. ${ }^{24}$ The crucial doctrine established in the previous Meditations for the proof is that God cannot be a deceiver and so, this natural impetus, once restricted to the needs of the mind-body union, is not entirely deceitful. It can be trusted when it teaches us that our perceptions of external material objects are caused by these objects. But the belief that our perceptual ideas resemble the external objects is "true" only pragmatically, not metaphysically. The impulse of nature, understood as the mind/body union, is not fallacious, for it is not a faculty of metaphysical knowledge (this is the intellect, which belongs only to the mind), but a faculty necessary to our survival. If we did not feel the irresistible feeling that makes us strongly believe that fire exists as an independent external material object which is warm we would not avoid putting our hands on it. Moreover, Descartes is aware that since his argument for the existence of external

23 "Now there is in me a passive faculty of sensory perception, that is, a faculty for receiving and recognizing the ideas of sensible objects; but I could not make sense of it unless there was also an active faculty, either in me or in something else, which produced or brought about these ideas. But this faculty cannot be in me, since clearly it presupposes no intellectual act on my part, and the ideas in question are produced without my cooperation and often even against my will. So the only alternative is that it is in another substance distinct from me ... This substance is either a body ... or else it is God, or some creature more noble than a body ... But since God is not a deceiver, it is quite clear that he does not transmit the ideas to me either directly from himself, or indirectly, via some creature ... For God has given me no faculty at all for recognizing any such source for these ideas; on the contrary, he has given me a great propensity [Latin: "magnam propensionem"; French: "très grand inclination"] to believe that they are produced by corporeal things. So I do not see how God could be understood to be anything but a deceiver if the ideas were transmitted from a source other than corporeal things. It follows that corporeal things exist" (CSM, II, $55)$.

24 "The only proof that could be given me of this [the existence of bodies] would be based on the contention that God would be deceiving me if he imprinted in my mind the ideas that I have of bodies without there actually being any. But this proof is very weak: it proves too much. Ever since the beginning of the world, all mankind, except perhaps one out of two hundred millions, has firmly believed that bodies are colored, and that this is an error. I ask, does God deceive mankind with regard to colors? If he deceives them about this, what prevents him from so doing with regard to extension?" (Bayle, 1991, p. 198). 
material bodies depends on a sentiment felt by the mind/body union, it cannot be a demonstration, unlike his arguments for the existence of God and the mind/body distinction. In the synopsis of the Sixth Meditation, he presents this impossibility as something positive to the extent that it corroborates one of his main theses in the "Meditations", namely, that the existence of material things is less certain than that of immaterial things (God and the mind). The fact that it is not possible to demonstrate the existence of external material objects is entirely harmless, says Descartes, "since no sane person has ever seriously doubted these things" (CSM, II, 11). Descartes is not saying in the Sixth Meditation that the doubt of the First Meditation was not serious. What he means is that such doubt holds only in the very special metaphysical, Hume says, "philosophical", exercise of the Meditations. In ordinary life the force of the natural impulse makes the ordinary man and the philosopher firmly believe in the existence of the external material world. This is further evidence of how imbued of the content of Descartes's "Meditations" Hume was when he wrote part I and the end of part II of section XII. ${ }^{25}$

This leads to the second philosophical skeptical consequent argument about the senses. It concerns the primary/secondary qualities distinction. As it was argued by Bayle, ${ }^{26}$ if the latter are only in the mind, so are the former. This is the occasion Hume cites Berkeley and Bayle in section XII. But remounting to the origins of the argument, Bayle cites Simon Foucher as his source. Foucher's project was to revive Academic skepticism after Descartes. He agreed with Augustine's view that the New Academics secretly held Plato's doctrines and exoterically attacked Stoic materialism. According to Foucher, Descartes, in combatting materialism through a radical doubt about the external material world, was a follower of the Academic skeptics, but when he attempted to prove the existence of this world in the Sixth Meditation he fell pray of that deceiving bodily natural impetus. As Watson (1991) and Popkin (2003, pp. 276-277) have shown, Foucher misunderstood

25 "a Pyrrhonian cannot expect, that his philosophy will have any constant influence on the mind ... he must acknowledge ... that all human life must perish, were his principles universally and steadily to prevail” (E, p. 160). See Bayle: "Society has no reason to be afraid of skepticism ... only religion... has anything to fear from Pyrrhonism. ... But this should not be a cause of uneasiness. There never were, and there never will be more than a small number of people who can be fooled by the arguments of the skeptics. The grace of God in the faithful, the force of education in other men, and, even if you wish, ignorance and the natural inclination to reach decisions, all these constitute an impenetrable shield against the arrows of the Pyrrhonists although this sect thinks it more formidable today than it was in former times" (Bayle, 1991, pp. 195-196). Hume opens section XII with precisely Bayle's view: "The Sceptic is another enemy of religion, who naturally provokes the indignation of all divines and graver philosophers; though it is certain, that no man ever met with any such absurd creature" (E, p. 149).

26 See footnote number 24 above. 
Descartes's position, according to which the primary qualities are not sensible qualities really existent such as they are perceived in the external material world. Likewise, Hume's second skeptical argument about the existence of an external material world does not strike Descartes but an empiricist such as Locke. $^{27}$

I have briefly mentioned Hume's second skeptical argument against the senses just to show that, like the previous one, it is also modern, having the ancients being dismissed at the outset. The same holds for the "natural instincts," whose immediate background is Cartesian.

It might be argued that though Descartes talks of impetus and impulse as an irresistible feeling that determines assent independently of reason, he does not talk of "instinct." Moreover, Descartes's view of nature in the Sixth Meditation is metaphysically grounded on God and his creation. It will therefore be useful to bring a "Cartesian skeptic" who dismissed metaphysics. ${ }^{28}$ Hume's conclusion of the first philosophical skeptical argument against the senses is a dilemma: "if [the opinion of external existence] rested on natural instinct, [it] is contrary to reason, and if referred to reason, [it] is contrary to natural instinct" (E, p. 155). This brings to mind the "deplorable" condition in which Hume finds himself at the conclusion of the first book of the "Treatise" (pp. 263-274) torn between reason, which shows the lack of justification of his basic beliefs, and nature, which makes him believe them anyway. The dilemma resembles Pascal's tragic description of man-"la nature confond les pyrrhoniens et la raison confond les dogmatiques"-in a way such that neither can the skeptic suspend judgment upon verifying the lack of reason of his beliefs about the external world nor can the dogmatic philosopher rationally justify these beliefs which he cannot but hold..$^{29}$ This opposition is established by Pascal in terms of, on the one hand, instinct and sentiment, and, on the other, reason and skepticism (see La 110, 112, 128, 131). The opposition of skepticism and sentiment in Hume, which may be remotely and indirectly

27 "Bereave matter of all its intelligible qualities, both primary and secondary, you in a manner annihilate it, and leave only a certain unknown, inexplicable something, as the cause of our perceptions; a notion so imperfect, that no sceptic will think it worth while to contend against it" (E, p. 155). See Locke's "Essay": "if any one will examine himself concerning his Notion of pure substance in general, he will faint he has no other Idea of it at all, but only a Supposition of he knows not what support of such Qualities which are capable of producing simple Ideas in us" (1975, p. 295).

28 Pascal, "Pensées", La 149, 189, 190, 191, 449. Pascal believed that natural theology was useless and that deism was as contrary to Christianity as atheism.

29 Pascal, "Pensées", La 131. Hume may have become acquainted with Pascal's dilemma either directlyHume was well aware of French philosophy and the "Pensées" were translated to English in 1688-or indirectly through Bayle who cites this passage of Pascal's in remark C of the article "Pyrrho" of the "Dictionary". 
related to the ancient Pyrrhonians,${ }^{30}$ is directly related to the modern Cartesian skeptics. $^{31}$

\section{Antecedent skepticism}

That Descartes is the main proponent of antecedent skepticism is evident in Hume's claim that it was "much inculcated by Descartes and others" (E, p. 149). Furthermore, Hume calls "Cartesian doubt" its extreme species, which he rejects. Descartes's doubt in the First Meditation (CSM, II, 14) about the reliability of our faculties is best summarized by Pascal who qualifies it, like Hume, as "Pyrrhonian."

Les principales forces des pyrrhoniens ... sont que nous n'avons aucune certitude de la vérité de ces principes [space, time, movement, number], hors la foi et la révélation, sinon en (ce) que nous le sentons naturellement en nous. Or ce sentiment naturel n'est pas une preuve convaincante de leur vérité, puisque n'y ayant point de certitude hors la foi, si l'homme est créé par un dieu bon, par un démon méchant ou à l'aventure, il est en doute si ces principes nous sont donnés ou véritables, ou faux, ou incertains selon notre origine. (La 131)

If the scope of universal doubt comprises not only our beliefs but also our faculties, it is impossible to resolve this doubt philosophically without begging the question.

Hume argues that the Cartesians cannot refute such doubt. Even if the cogito were "self-evident," an "original principle" with a "prerogative above others," we would not be able "to advance a step beyond it, but by the use of those very faculties, of which we are supposed to be already diffident" (E, p. 150). This is one of Huet's objections to Descartes, first that the cogito is not self-evident, and second that, even if it were, nothing could be derived from it with certainty since the veracity of our reasoning faculty was put in doubt by the hypothesis of the deceiver. ${ }^{32}$ Foucher $(1693$, p. 188) accepted the cogito,

30 See Annas' suggestion above.

31 Skeptical Cartesian sources could also be given to Hume's consequent skepticism about reason and about reasonings concerning matters of fact. For the first, he cites Berkeley and Bayle (see article "Zeno of Elea" of the "Dictionary"). The relevance of Malebranche for the second is well known. See, for instance Kail (2008). Popkin (1953) has argued that Glanvill is another possible source. There have been also discussions about medieval antecedents of Hume's inductive skepticism, in particular by Al-Ghazali and Nicholas of Autrecourt (on the first, see Kukkonen, 2010, on Nicholas see Grellard, 2005).

32 "ce doute est de telle importance pour empêcher nos Esprits de recevoir aucune proposition comme certain, tant que nous ne nous servirons que de nôtre Raison, que tant s'en faut que Des Cartes l'ait détruit, mais même qu'il ne peut aucunement être détruit, si la Raison n'enprunte le secours de la Foi" (Huet, 1974, pp. 86-87). See also Huet's "Against Cartesian Philosophy", chapter 1, 5: "Descartes begs the question" [in the cogito]; 7: "I am thinking' is not the first notion of all"; 11: "It is false that the proposition 'I am thinking, 
but held that the steps taken further by Descartes were inconsistent with his skeptical scenarios. ${ }^{33}$

Pascal, Huet and Bayle claimed that Descartes's hyperbolic doubt could be resolved only supernaturally by Grace, or by blindly accepting from Scripture that God is not a deceiver. However, Pascal and Bayle held that such doubt cannot be sustained, except momentarily, since the feeling of nature is too strong to let skeptical reason lead to suspension of judgment. Before them, Gassendi “approved," like Hume, Descartes's “project for freeing [his] mind from all preconceived opinions" (CSM, II, 180), but, also like Hume, considered Descartes's doubt in the First Meditation impossible to be held. ${ }^{34}$

The aim of antecedent skepticism of preserving the inquirer from "error and precipitate judgment" was the main recommendation made by the early modern skeptics. According to Hume, this is done by moderating the previous species of antecedent skepticism, that is, by not considering our intellectual faculties as completely unreliable but, recognizing their fallibility, that they must be employed with caution. This species of antecedent skepticism is nothing but the Academic skepticism recommended in part III, which is also a moderation of the excessive or "Pyrrhonian" (that is, Cartesian) type of skepticism. ${ }^{35}$ It corresponds to Descartes's methodic rules in the second part of the "Discourse on the Method" and in the "Rules for the Direction of

therefore I am' is known by us through a simple perception, rather than by reason"; 12: "'I am thinking, therefore I am' is refuted by Descartes's argument based on doubting, that we do not know whether we were created by God, or by some evil demon, with the result that we always err"; and 15: "Descartes admits that we have no rule of truth unless he establishes that we were not created by God so as always to err"; "When Descartes tries to overturn the [skeptics'] doctrine, he greatly strengthens it with the argument ... that we do not know whether we were created by God as always to err. For since he had nothing to rebut this argument but the contradiction that if we had been created by God so as always to err, He would be a deceiver, and since I have shown that this does not comport with the rest of his doctrine, it is obvious that nothing more advantageous to the sect of skeptics and Academics could have been advanced. For the Cartesians, as well as Descartes himself, all concede that unless it is established that we were not made by God so as always to err, we cannot know whether the theorems of geometry are certain, or whether the visible world exists as it appears to exist" (Huet, 2003, pp. 111-112).

33 Descartes claims in the "Meditations" that the deceiver does not put in question clear and distinct perceptions such as the cogito. The deceiver must be refuted only to guarantee the validity of our reasonings, which depends on memory (see CSM, II, 100-102, 171). But the issue is controversial among Cartesian scholars.

34 See also the title of chapter X of Glanvill's "Scepsis Scientifica": "A third reason of our Ignorance and Error, viz., the impostures and deceits of our Senses. The way to rectifie these misinformations propounded. Descartes his method the only way to Science. The difficulty of exact performance."

35 The main point of the Academic skeptics was to avoid precipitation that might lead to error and to keep intellectual integrity, "by preserving a proper impartiality in our judgments, and weaning our mind from all those prejudices, which we may have imbibed from education or rash opinion" (E, p. 150). See Cicero's Ac II.66-67; 77 and, in particular Ac II.8: "hoc liberiores et solutiores sumus, quia integra nobis judicandi potestas manet." 
the Mind". ${ }^{36}$ "To begin with clear and self-evident principles" corresponds to Descartes's first rule "to include nothing more in my judgements than what presented itself to my mind so clearly and so distinctly that I had no occasion to doubt it." "To advance by timorous and sure steps" corresponds to Descartes's third rule "to [begin] with the simplest and most easily known objects in order to ascend little by little, step by step, to knowledge of the most complex"; and "to review frequently our conclusions, and examine accurately all their consequences" corresponds to Descartes's fourth rule "to make enumerations so complete, and reviews so comprehensive, that I should be sure of leaving nothing out" (CSM, I, 120). Descartes's rules, Foucher holds, are the Academic rules of philosophize which were ignored by scholastic philosophers. ${ }^{37}$ Descartes must be praised, according to Foucher (1687, pp. 111-114), for recovering them at the outset of his philosophy but criticized for violating them when he develops his metaphysics.

I can here only very briefly trace down how Hume came to recommend and adopt antecedent Academic skepticism in the first Inquiry. This ancient view was recovered against the scholastics by an associate of Petrus Ramus (who attempted a reform of the University of Paris in the mid-sixteenth century) named Omer Talon. Talon published Cicero's "Academica" and, in a commentary (1547), showed how the intellectual freedom exercised by the Academic skeptics corresponded to genuine philosophical practice (not subservient to Aristotelianism nor to any dogmatic system, even Plato's). ${ }^{38}$ Montaigne also valued much the integrity of the Academic skeptics and he and Talon influenced Pierre Charron's "De la Sagesse", who supported an Academic skeptical view of wisdom which was extremely influential in the seventeenth century. ${ }^{39}$ But as Descartes became famous by pretending to found with his Academic doubt a new dogmatism observing the Academics' philosophical rigor and integrity, Foucher, Huet and Bayle had to separate Descartes's methodical doubt such as reported in the second part of the "Discourse" from Descartes's metaphysical doubt-which according to them challenged rationality and aimed not at avoiding prejudices and precipitation

36 I have shown above that Hume certainly read Cicero's "Academica". But as the whole context of the discussion of skepticism in section XII is Cartesian and Descartes is mentioned in connection to antecedent skepticism, it is much more probable that he and his skeptical disciples are Hume's sources.

37 Foucher's Academic rules, which he says are similar to Descartes's in the "Discourse", are 1/ to conduct oneself only by demonstration; 2/ to not raise issues which we see we cannot resolve; 3 / to recognize that one does not know that of which one is in fact ignorant; 4/ to draw a clear difference between the things one knows and those one does not know; and 5/ to search always for new knowledge. See Foucher (1687, pp. 5-8) and Watson (1987, pp. 36-45).

38 On Talon, see Schmitt (1972, pp. 81-91) and Naya (2008).

39 See Maia Neto (2014). 
but at persuading metaphysical doctrines. These two kinds of Cartesian doubt correspond, respectively, to the "more moderate" antecedent skepticism that "is a necessary preparative to the study of philosophy," and to the antecedent skepticism which Hume says would be "incurable" "were it ever possible" (E, p. 150).

\section{Academic skepticism}

Hume's Academic skepticism also has two "species," but unlike the cases of antecedent and consequent skepticism, both are endorsed. The first is the good species of antecedent skepticism just mentioned: the caution, moderation, and intellectual integrity, characteristics of the Academic way of philosophize, which was recovered by Renaissance and seventeenth-century philosophers. Of these, I would highlight the role-even if indirect-played by Charron. He wrote a book "Of Wisdom" that was a best seller in the first half of the seventeenth century. It was almost immediately translated to English, where it had 12 editions in the seventeenth-century. ${ }^{40}$ Charron (1986, p. 401 and p. 839) qualifies his wisdom as Academic skeptical, Cicero being his main source among the ancients. His skeptical wise man is opposed above all to the opinionated and the superstitious man. ${ }^{41}$ Strong attachment to opinions is a major obstacle to the exercise of intellectual integrity and freedom that characterizes the wise man since he exercises the human intellectual faculties in their perfection (which do not include attainment of truth, only inquiry after it). Charron mentions three degrees of presumption: $1 /$ to believe without examination ("vice ordinaire en la condition humaine"); 2 / to affirm dogmatically what is believed; and 3/ to attempt to impose it to others (1986, pp. 275-278). This corresponds to Hume's view that

the greater part of mankind are naturally apt to be affirmative and dogmatical in their opinions; and while they see objects only on one side, and have no idea of any counterpoising argument, they throw themselves precipitately into the principles, to which they are inclined ... But could such dogmatical reasoners become sensible of the strange infirmities of human understanding, even in its most perfect state, and when most accurate and cautious in its determination; such a reflection would

40 Cf. Desan (2009, pp. 5-7).

41 According to the frontispiece of the book, skeptical wisdom has four enemies: opinion (he means strong attachment to opinions), superstition, science (he means dogmatic science) and passion (when not controlled by reason). 
naturally inspire them with more modesty and reserve, and diminish their fond opinion of themselves, and their prejudice against antagonists (E, p. 161). ${ }^{42}$

Furthermore, Charron identifies religion as the field in which nonrationally based attachment to opinions is most common and dangerous. It was above all as a critic of the Christian religion that he was read in the seventeenth and early eighteenth century by free thinkers. Even if Hume did not read Charron's "Wisdom", he certainly knew and much-appreciated Bayle's "Dictionary", whose article on Charron emphasizes his intellectual integrity, his fight against superstition, and the persecution he suffered from Christian apologists (in a way similar to that suffered by Bayle himself). ${ }^{43}$ This might explain Hume's remark in section V that "It is surprising ... that this philosophy [Academic skepticism]... should be the subject of so much groundless reproach and obloquy. ... By flattering no irregular passion, it gains few partisans: By opposing so many vices and follies, it raises to itself abundance of enemies, who stigmatize it as libertine, profane, and irreligious" (E, p. 41). ${ }^{44}$ The second aspect of Hume's Academic skepticism, the idea of circumscribing the investigation to what our limited faculties can attain is even more modern than the first aspect. We see it in Descartes's "Rules" (in which what is appropriate for human mind is different from Hume's view), in Foucher's Academic rules and in Locke's "Essay" whose purpose is precisely to discourage inquiry on what we cannot have certainty (metaphysics) and turn it to ordinary practical things.

I do not claim that ancient skepticism is relevant for Hume's skepticism only indirectly. I agree with the scholars who have argued that if Hume's "sceptical doubts concerning the operations of the understanding" (section IV) are basically modern, ancient skepticism is directly relevant in his "sceptical solution of these doubts" (section V). ${ }^{45} \mathrm{He}$ recommends it as the kind of

42 Another possible source of Hume on this regard is Bayle's article "Chrysippus," remark G, of the "Dictionary", in which he opposes the Stoic to the Academic skeptic by comparing the Stoic's way of philosophizing to the reasoning of a lawyer, which is previously committed to a cause, and the Academic to an uncommitted reporter-i.e., the critical reporter as he sees himself as the author of the Historical and Critical Dictionary.

43 See Bayle, "Dictionary", article "Charron," notes F, I, K, L, and O. The religious zealot who most persecuted Bayle was Pierre Jurieu, whose view on belief and faith is pointed out by Popkin (1967) as a possible source of Hume's own view.

44 Hume may also be referring to Crousaz who attacked Bayle's skepticism mainly on the grounds that it was irreligious and immoral. See Paganini (2010, pp. 191-206).

45 See, besides Annas and Popkin discussed in section (I) above, Wright (1986) and Stroud (1991). 
intellectual activity one ought to pursue, instead of superstitious religion and dogmatic philosophy. ${ }^{46}$

The main evidence that ancient Academic skepticism is directly relevant to Hume's view of Academic skepticism is external to the first Inquiry. This evidence is Philo, the main character of Hume's "Dialogues Concerning Natural Religion". ${ }^{47}$

Is Philo a pure skeptic, with no commitment at all with religion as Cleanthes and his pupil Pamphilus, the reporter of the dialogue, suggest he is, ${ }^{48}$ and as he himself seems to suggest at certain occasions ${ }^{49}$ or is he, as he claims, ${ }^{50}$ a sincere supporter of Christianity in the line of the skeptical fideism vindicated, according to most scholars insincerely and only to avoid persecution, by many of his modern skeptic predecessors ${ }^{51}$

Before Hume, other early modern philosophers choose the dialogue to present skeptical views. ${ }^{52}$ Of these, the most relevant is La Mothe Le Vayer, the only avowed early modern skeptic I am aware of before Hume. La Mothe

46 Did Hume know Pascal's "Entretien avec Sacy sur Montaigne et Épictète"? It was first published in 1728 and "il fut publié de nouveau à plusieurs reprises dès le XVlle siècle" (Mesnard, 1991, p. 77). In this dialogue, Pascal opposes skepticism (represented by Montaigne) and philosophical dogmatism (represented by Stoicism in the person of Epictetus) to argue that both are unsatisfactory in a way that recommends Christianity. At the beginning of section V, Hume opposes Christianity and dogmatic philosophy (represented by Stoicism-he also cites Epictetus) to recommend Academic skepticism.

47 Annas (2000, p. 148n) notices that Hume's view of ancient skepticism in the "Dialogues" is much more correct than in the first Inquiry. Notice also that, unlike the first Inquiry, in the "Dialogues" the ancient skeptics are explicitly referred: "ancient Pyrrhonians" (part I, p. 5); "ancient Academics" (part I, p. 10). Philo repeats Hume's evaluation of the practical benefits of Academic skepticism in section XII of the first Inquiry: "if a man has accustomed himself to skeptical considerations on the uncertainty and narrow limits of reason, he will not entirely forget them when he turns his reflection on other subjects" ("Dialogues", p. $6)$.

48 At one occasion when Philo says that the recognition of the "narrow limits of human reason" would be a way towards embracing Christianity, Pamphilus perceived in Cleanthes' semblance "some raillery or artificial malice in the reasonings of Philo" ("Dialogues", p. 5).

49 "All religious systems, it is confessed, are subject to great and insuperable difficulties. Each disputant triumphs in his turn, while he carries on an offensive war, and exposes the absurdities, barbarities, and pernicious tenets of his antagonists. But all of them, on the whole, prepare a complete triumph for the sceptic, who tells them that no system ought ever to be embraced with regard to such subjects; for this plain reason, that no absurdity ought ever to be assented to with regard to any subject. A total suspense of judgment is here our only reasonable resource. And if every attack, as is commonly observed, and no defense among theologians is successful, how complete must be his victory who remains always, with all mankind, on the offensive, and has himself no fixed station or abiding city which he is ever, on any occasion, obliged to defend?" ("Dialogues", p. 53). Another evidence is Philo's suggestion that his arguments are ad hominem, always targeting some position and never representing his own position. For instance, when Demea complains at Philo's claim that there is no certainty in any theistic argument (neither in the a priori supported by Demea nor in the a posteriori supported by Cleanthes), he says: "I argue with Cleanthes in his own way" ("Dialogues", p. 24).

50 "I am indeed persuaded, said Philo, that the best and indeed the only method of bringing everyone to a due sense of religion is by just representations of the misery and wickedness of men" ("Dialogues", pp. 81-82).

51 "Modern" skepticism here is not restricted to Cartesian skepticism.

52 The famous Remark B of the article "Pyrrho" in Bayle's "Dictionary" is a dialogue held by two abbots. 
wrote "dialogues faits à l'imitation des anciens," ${ }^{53}$ which describes exactly the formal structure of Hume's “Dialogues". Like Hume's, La Mothe's skepticism aimed above all at combatting superstition. Most commentators consider him a libertine engaged in criticizing the Christian religion and his avowed fideism just a mask to deceive the authorities and the naive reader. ${ }^{54}$ According to these interpreters, the dialogue is crucial in this strategy since it reproduces in literary form the free conversations held in private by men of letters liberated from the intellectual tyranny of religion. Libertinus etymologically means the former slave who has conquered his freedom. ${ }^{55}$ However, when Philo makes his final fideist claim Demea is no longer present and he and Cleanthes enjoy "unreserved intimacy" ("Dialogues", p. 77). Because Cleanthes also says that Philo has an "abhorrence of vulgar superstition" (ibid.), we may consider the possibility of Philo being an Academic skeptic opposed to superstition but not irreligious.

Why did Hume choose the name of Philo for his skeptic? There were two Philos in Hellenistic philosophy and both dealt with skepticism. Philo of Alexandria was the first to use ancient Pyrrhonism to support (Jewish) fideism. ${ }^{56}$ If he is the model, the hypothesis of a fideist Philo gains plausibility. ${ }^{57}$ The other Philo, of Larissa, was the last of the Academic skeptics and the teacher of Cicero, who Hume admired so much and who wrote a dialogue on the nature of the gods that is probably the direct model of Hume's "Dialogues" ${ }^{58}$ If Philo of Larissa is the model, the position of Hume's character would be contrary to natural theologies (such as Stoicism), that is, the attempt to ground religious belief on philosophical reasoning, but not irreligious. Note that I am not saying that it would be necessarily religious and Christian, for this might imply Hume's agreement with Augustine's and Foucher's view that Philo and the other Academic skeptics were secret Platonists, hiding Plato's metaphysical truths from Stoic materialism and pantheism until the arrival of

53 This is the title of two sets of skeptical dialogues, published by La Mothe Le Vayer anonymously and with false place and date of publication.

54 The most influential of these interpretations is Pintard's (1983), first published in 1943.

55 See, for instance, Bury (2002).

56 Cf. Levy (2010).

57 The most famous fideist statement of Philo's is his concluding remark in the "Dialogues" that "[t]o be a philosophical skeptic is, in a man of letters, the first and most essential step towards being a sound, believing Christian" ("Dialogues”, p. 89).

58 Hume's dialogue seems modeled upon Cicero's "De Natura Deorum". Their dramatic structures are similar. In the case of Cicero's, he is the witness of a debate between Cota, the Academic skeptic, Vellius, an Epicurean, and Balbus the Stoic. Cicero and Cotta "are disciples of Philo, and have learned from him to know nothing" (Cicero, "Nat. Deor." I.17). The main issue examined in both dialogues is the argument from design. Cicero's dialogue is cited in Hume's "Dialogues" (part V, pp. 34-35). Hume's source for the Simonides' anecdote (part II, pp. 20-21) probably is "Nat. Deor." I.60. 
Christianity might make these doctrines available to all humankind through revelation. However, the rejection of this legend does not mean that the Academic skeptics denied a transcendent God. ${ }^{59}$ If not Philo's and Cicero's, this certainly was Plutarch's position which was rehearsed by Montaigne, Charron and other early modern skeptics who claimed that natural theology violated this transcendence thereby incurring in superstition. ${ }^{60}$ Philo of Larissa is also relevant to Hume since he mitigated the skepticism of his predecessors Arcesilaus and Carneades by allowing that the wise man assent, in a fallibilist fashion, to the probable impression, which is how Hume's Philo supports a kind of minimalist natural theology at the end of the "Dialogues". This reading is in agreement with Bayle's judgment of Charron and Hume's judgment of Academic skepticism since it does not "stigmatize ... as libertine, profane, and irreligious" (E, p. 41) Hume's own Academic skepticism.

\section{Bibliography}

ANNAS, J. "Hume and Ancient Skepticism". In: Ancient Scepticism and the Sceptical Tradition. Ed. J. Sihvola. Helsinki: Acta Philosophica Fennica, 2000.

ARNAULD, A., NICOLE, P. “Logique de Port-Royal”. Paris: Flammarion, 1970.

BAYLE, P. "Historical and Critical Dictionary: selections". Edition and translation by R. Popkin. Indianapolis: Hackett, 1991.

BAXTER, D. "David Hume". In: Skepticism: From Antiquity to the Present. Eds. D. Machuca and B. Reed, forthcoming.

BURNYEAT, M. "Idealism and Greek Philosophy: What Descartes saw and Berkeley missed". The Philosophical Review, Vol. 91, pp. 3-40, 1982.

. "Can the Skeptic Live His Skepticism". In: Doubt and Dogmatism. Eds.

M. Schofield, M. Burnyeat, and J. Barnes. Oxford: Oxford U. Press, 1980.

BURY, E. "Écriture libertine et sources doxographiques: le cas de La Mothe Le Vayer". Libertinage et Philosophie au XVII Siècle, Vol. 6, pp. 19-36, 2002.

CHARRON, P. "De la Sagesse”. Ed. B. de Negroni. Paris: Fayard, 1986.

CICERO, M. T. "Academica”. Translation by H. Rackham. Loeb Classical Library. Harvard: Harvard U. Press, 1933.

CURLEY, E. "Descartes Against the Skeptics". Cambridge: Harvard U. P, 1978. DESAN, Ph. "Pierre Charron, théologien et philosophe". Corpus: Revue de Philosophie, Vol. 55, pp. 5-7, 2009.

59 According to Levy (2008, p. 29), the rejection of Augustine's interpretation "ne signifiait pas pour autant nécessairement une renonciation totale à la transcendance. En affirmant la faiblesse de l'intellect humain, Arcésilas laissait exister en creux la possibilité, jamais explicitement assumée, que ce qui n'était pas possible pour l'âme dans ce monde le fût ailleurs."

60 In the "Dialogues" (part I, p. 3), Hume cites Plutarch's "De stoicorum repugnantis". 
DESCARTES, R. "Eeuvres". 12 Vols. I-XII. Eds. Ch. Adam and P. Tannery (AT for short). Paris: J. Vrin, 1996.

. "The Philosophical Writings". 2 Vols. Translation by J. Cottingham, R.

Stoothoff and D. Murdoch (CSM for short). Cambridge: C.U.P., 1984.

DIOGEMES LAERTIUS. "Lives of Eminent Philosophers". Translation by R. D. Hicks. Loeb Classical Library. Cambridge: Harvard U. Press, 1925.

FOUCHER, S. "Dissertation sur la Recherche de la Vérité, contenant l'Apologie des Académiciens". Paris: Estienne Michallet, 1687.

"Dissertation sur la Recherche de la Vérité, contenant l'Histoire et les Principes de la Philosophie des Académiciens, avec plusieurs réflexions sur les sentimens de M. Descartes". Paris: Jean Anisson, 1693.

GLANVILL, J. "Scepsis Scientifica”. New York, London: Garland, 1978.

GRELLARD, C. "Croire et savoir: les principes de la connaissance chez Nicolas d'Autrecourt". Paris: Vrin, 2005.

GROARKE, L., SOLOMON, G. "Some Sources for Hume's Account of Cause". Journal of the History of Ideas, Vol. 52, pp. 645-663, 1991.

HUET, P.-D. “Against Cartesian Philosophy”. Translation by T. Lennon. Amherst: Humanity, 2003.

$\overline{\text { Olms, } 1974 .}$

. "Traité philosophique de la foiblesse de l'esprit humain". Hildesheim:

. "An Essay Concerning the Weakness of Human Understanding". Translation by E. Combe. London: Matthew de Varenne, 1725.

HUME, D. "Dialogues Concerning Natural Religion". Ed. R. Popkin. Indianapolis: Hackett, 1986.

. "A Treatise of Human Nature". Eds. L. A. Selby-Bigge and P. H. Nidditch. Oxford: Oxford University Press, 1978.

. "Enquires Concerning Human Understanding and Concerning the Principles of Morals". Eds. L. A. Selby-Bigge and P. H. Nidditch. Oxford: Clarendon Press, 1975.

KAIL, P. "On Hume's Appropriation of Malebranche: Causation and Self". European Journal of Philosophy, Vol. 16, pp. 55-80, 2008.

KUKKONEN, T. "Al-Ghazali's Skepticism Revisited". In: Rethinking the History of Skepticism: The Missing Medieval Background. Ed. H. Lagerlund. Leiden: Brill, 2010. pp. 29-59.

LA MOTHE LE VAYER, F. "Dialogues faits à l'imitation des anciens". Ed. A. Pessel. Paris: Fayard, 1988.

LEVY, C. "The sceptical Academy: decline and afterlife". In: The Cambridge Companion to Ancient Scepticism. Ed. R. Bett. Cambridge: Cambridge University Press, 2010. pp. 81-104.

. "Les scepticismes". Paris: PUF, 2008.

LOCKE, J. “An Essay Concerning Human Understanding”. Ed. P. Nidditch. Oxford: Clarendon, 1975. 
MAIA NETO, J. "Academic Skepticism in Seventeenth-Century French Philosophy. The Charronian Legacy 1601-1662”. Dordrecht: Springer, 2014.

MESNARD, J. "Introduction to Pascal's Entretien avec M. de Sacy". In: Pascal Euvres complètes, Vol. 3. Ed. J. Mesnard. Paris: Desclée de Brouwer, 1991.

MONTAIGNE, M. "The Essays". Translation by M. A. Screech. London: Penguin, 1991.

NAYA, E. 'Le 'coup de Talon' sur l'impiété: scepticisme et vérité chrétienne au XVI siècle". Les Études Philosophiques, Vol. 2, pp. 141-160, 2008.

PAGANINI, G. "Le scepticisme: une maladie ou un remède? Bayle, Crousaz, Hume". Libertinage et Philosophie, Vol. 12, pp. 191-206, 2010.

PASCAL, B. "Pensées". In: Euvres complètes. Ed. Louis Lafuma (La for short). Paris: Éditions du Seuil, 1963.

PINTARD, R. "Le Libertinage érudit dans la première moitié du XVII siècle. Nouvelle édition augmentée d'un avant-propos et de notes et réflexions sur les problèmes de l'histoire du libertinage". Genève-Paris: Slatkine, 1983.

POPKIN, J. "Richard Popkin and his History of Scepticism". In: Skepticism in the Modern Age. Building on the work of Richard Popkin. Eds. J. Maia Neto, G. Paganini and J. Laursen. Leiden: Brill, 2009. pp. 15-34.

. "In His Own Words: Richard Popkin's Career in Philosophy". In: The Legacies of R. Popkin. Ed. J. Popkin. Dordrecht: Springer, 2008. pp. 259-293.

POPKIN, R. "The History of Scepticism from Savonarola to Bayle". Oxford: Oxford University Press, 2003.

. "Sources of Knowledge of Sextus Empiricus in Hume's Time". Journal of the History of Ideas. Vol. 54, pp. 137-141, 1993.

. "Intellectual autobiography: warts and all". In: The Sceptical Mode in Modern Philosophy. Essays in Honor of Richard H. Popkin. Eds. R. Watson and J. Force. Dordrecht: Martinus Nijhoff, 1988. pp. 103-149.

. "The High Road to Pyrrhonism". Eds. R. Watson and J. Force. San Diego: Austin Hill Press, 1980.

. "Hume and Jurieu: possible Calvinist origins of Hume's Theory of Belief".

Rivista Critica di Storia della Filosofia, Vol. 4, pp. 400-417, 1967.

. "Joseph Glanvill: A Precursor of Hume". Journal of the History of Ideas, Vol. 14, pp. 292-302, 1953.

"David Hume and the Pyrrhonian Controversy". The Review of Metaphysics, Vol. 6, pp. 65-81, 1952.

SCHMITT, Ch. "Cicero Scepticus: A Study of the Academica in the Renaissance". The Hague: Martinus Nijhoff, 1972.

STROUD, B. "Hume's Scepticism: Natural Instincts and Philosophical Reflection". Philosophical Topics, Vol. 19, pp. 271-291, 1991.

TALON, O. "Academia, ejusdem in academicum Ciceronis fragmentaum explicatio". Paris: Mathieu David, 1547. 
WATSON, R. "Foucher's Mistake and Malebranche's Break: Ideas, Intelligible Extension and the End of Ontology". In: Nicolas Malebranche: his philosophical critics and successors. Ed. S. Brown. Assen: Van Gorcum, 1991. pp. 22-34.

Humanities, 1987. "The Breakdown of Cartesian Metaphysics". Atlantic Highlands: WRIGHT, J. "Hume's Academic Scepticism: A Reappraisal of His Philosophy of Human Understanding". Canadian Journal of Philosophy, Vol. 16, pp. 407-436, 1986. 